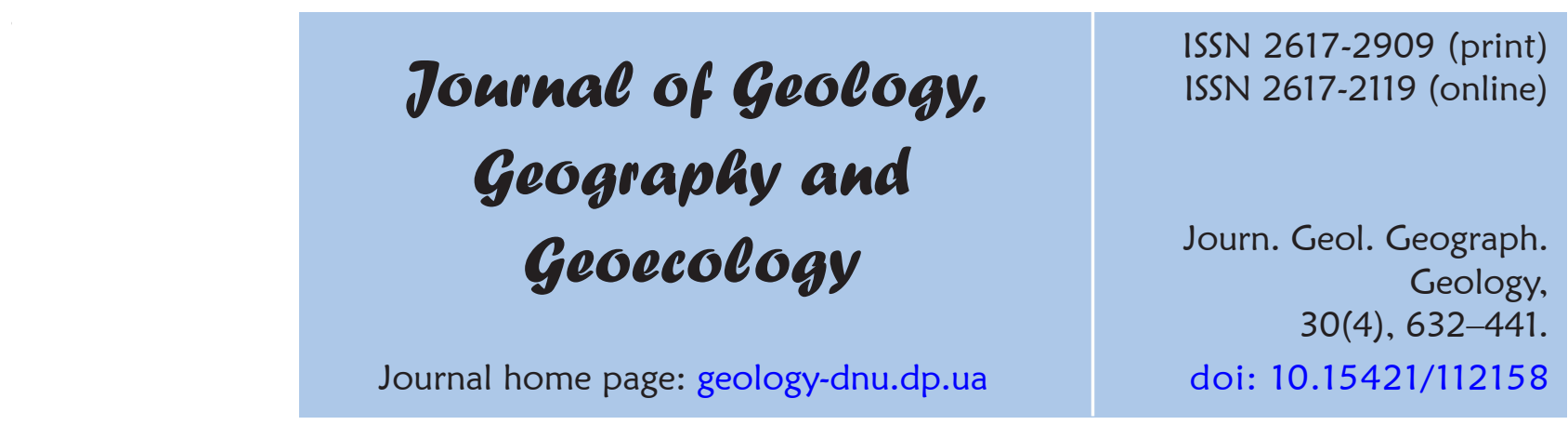

Dnistrianska N. I., Senkiv M.I., Ilnytska-Hykavchuk H. Ya., Haba M.I., Makar O.P. ～Journ. Geol. Geograph. Geoecology, 30(4), 632-641

\title{
Tourism potential of Ukraine in the context of geography and current state of German cultural heritage
}

\author{
Nataliia I. Dnistrianska, Mariana I. Senkiv, Halyna Ya. Ilnytska-Hykavchuk, Myroslava I. Haba, \\ Oksana P. Makar
}

Lviv Polytechnic National University, Lviv, Ukraine, mariana.i.senkiv@1pnu.ua

Received: 20.02.2021

Received in revised form: 06.03.2021

Accepted: 27.03.2021

German ethnic minority of the early XX century within the modern territory of Ukraine and geography of ethnic Germans and German cultural heritage in the modern Ukraine are developed. On the basis of a cluster analysis of indicators of the number of preserved objects and the number of former German settlements, groups of regions with high, medium and low potential for the development of ethnic tourism are identified. Odesa, Lviv, Zaporizhzhia, Kyiv and Zhytomyr are the leaders by the number of objects of German cultural heritage among all regions of Ukraine. The group of regions with a medium level of potential for ethnic tourism includes the Autonomous Republic of Crimea, Volyn, Kherson, Ivano-Frankivsk, Mykolaiv, Poltava, Chernivtsi, and Khmelnytskyi regions. Seven main types of preserved objects of German cultural heritage in Ukraine are identified. Sacred objects and public buildings and structures are best represented. The objects of German cultural heritage preserved to this day in the context of the regions of Ukraine are described. It was found that the main obstacles to the development of German ethnic tourism in Ukraine are the destruction of many cultural heritage objects, lack of funding for restoration of these objects, insufficient involvement of objects to tourist routes and low level of their promotion. The main ways to overcome these obstacles are identified: allocation of budget funds for the restoration of objects, attracting private investors, international organizations and German community; development of new tourist routes; marking places with information stands, publishing information materials about objects; digitalization of objects; organization of international conferences, round tables, festivals, etc.

Keywords: Germans, ethnicity, cultural heritage, tourism, tourism potential, tourism resource, church, cluster analysis.

\section{Туристичний потенціал України у контексті географії і сучасного стану німецької культурної спадщини}

\author{
Н.І. Дністрянська, М.І. Сеньків, Г.Я. Ільницька-Гикавчук, М.І. Габа, О.П. Макар
}

Національний університет «Львівська політехніка», Львів, Україна, mariana.i.senkiv@lpnu.ua

Анотація. У статті охарактеризовано теоретичні основи дослідження туристичного потенціалу областей України у контексті географії і сучасного стану німецької культурної спадщини. Вивчено історичні передумови формування та розвитку культурної спадщини німецької етнічної меншини на території сучасної України. Розроблено картосхеми географії німецької етнічної меншини початку XX ст. в межах сучасної території України та географії етнічних німців та німецької культурної спадщини в сучасній Україні. На основі кластерного аналізу показників кількості збережених об'єктів і кількості колишніх німецьких поселень виділено групи областей з високим, середнім та низьким потенціалом для розвитку етнічного туризму. Лідерами серед регіонів України за кількістю об’єктів німецької культурної спадщини є Одеська, Львівська, Запорізька, Київська та Житомирська області. До групи областей із середнім рівнем потенціалу етнічного туризму належать АР Крим, Волинська, Херсонська, Івано-Франківська, Миколаївська, Полтавська, Чернівецька, Хмельницька. Виокремлено сім основних типів збережених об'єктів німецької культурної спадщини в Україні. Найкраще представлені сакральні об'єкти та громадські будівлі і споруди. Охарактеризовано збережені до сьогодні об'єкти німецької культурної спадщини в розрізі областей України. 3'ясовано, що основними перешкодами розвитку німецького етнічного туризму в Україні є зруйнованість багатьох об'єктів культурної спадщини, відсутність фінансування для відновлення та реставрації цих об’єктів, недостатнє залучення об'єктів у туристичні маршрути та низький рівень їхньої популяризації. Визначено основні способи подолання цих перешкод: виділення бюджетних коштів для реставрації об'єктів, залучення приватних інвесторів, міжнародних організацій та німецьких спільнот; розроблення нових туристичних маршрутів; ознакування місць інформаційними стендами, видання інформаційних матеріалів про об'єкти; діджиталізація об’єктів; організація міжнародних конференцій, круглих столів, фестивалів тощо. 


\section{Introduction.}

The cultural heritage of each country, as a set of material and spiritual values and monuments, is directly related to the history of ethnic communities and groups living on its territory, and, therefore, is distinguished by diversity and regional differences. Knowledge of all ethnic components of the country's cultural heritage performs the functions of sociocultural mutual enrichment, understanding and cooperation. At the same time, the study of cultural heritage is also important in practice, as it can be used in educational and local history work and tourism (Polyvach, 2012). Taking into account the growing interest in the diverse achievements of diasporas and nostalgic motives of people from ancient settlements of national minorities, their cultural heritage can be of great attraction significance and become a factor in intensifying the development of inbound tourism in Ukraine, overcoming the depression of modern socioeconomic development of various settlements and areas.

One of the first definitions of cultural heritage is given by UNESCO in the Mexico Declaration on Cultural Policy: the cultural heritage of people includes works by artists, musicians, architects, writers, scientists, expressions of people's spirituality and a set of values that give meaning to life (UNESCO, 1982). It includes both tangible and intangible products, due to which the creativity of the people finds its expression: rituals, historical objects, monuments, literature, works of art, archives, etc.

Cultural heritage is a prerequisite for the development of tourism. These areas are interconnected. Tourism helps to attract public attention to historical and cultural objects, their preservation. We can talk about the cultural heritage of tourism, that is, elements of the human past as a resource, which include various reasons for the arrival of tourists: the desire to improve personal culture, learn something new, spend time with friends or family (Timothy, 2011). The relationship between cultural heritage and tourism is based on three concepts that combine as the main drivers of tourism interest: physical heritage, cultural diversity, and intangible heritage (Brooks, 2011).

The use of cultural heritage as a special tourism resource is effective only if this resource is combined and interacted with other necessary factors (entrepreneurial initiative, human labor and investment), which ensures the formation of tourism potential, the ability of destination to implement tourism services (Terebukh, 2016).

Historical and cultural heritage especially intensifies the development of nostalgic tourism, which includes trips to visit relatives; visiting places with which important events in a person's private life are connected; the history of the ethnic community which a person belongs to, or important moments in the life of the family, ancestors (Dorosh, 2020). There are two types of nostalgic tourists: real and historical. The first ones seek to revise their past cultural environment, to relive past events, last ones - to visit a specific environment that they have learned about from various sources (books, movies, stories) (Stern, 1992).

The development of ethnic cultural, cognitive and nostalgic tourism has every reason to be effectively combined with ecological, sports and health tourism, providing favorable conditions for the creation of multidisciplinary tourism and recreational clusters.

The purpose of the article is to reveal the peculiarities of the formation, distribution and current state of the cultural heritage of the German national minority in Ukraine in the context of the prospects of its use in tourism. Tasks: 1) to characterize the main stages and features of the settlement of ethnic Germans in Ukraine; 2) to reveal and cartographically reflect the modern geography of the German national minority; 3) substantiate the methodology for assessing the German cultural heritage in Ukraine as a tourism resource; 4) describe the current state of German cultural heritage objects in Ukraine and substantiate the possibilities of their use in tourism; 5) to reveal the problems of development of German ethnic tourism in Ukraine and to suggest ways of their solution.

\section{Materials and methods.}

The study is based on the use of two main sources of information: observations and analysis of secondary sources. The observations included visits to and descriptions of major cultural monuments and areas related to German cultural heritage in Ukraine. The works of national and foreign scholars on German cultural heritage, ethnic tourism, geography, history, management and marketing are analyzed. A number of secondary sources is also analyzed, in particular, statistics on the share of the German national minority in Ukraine in different years (population censuses), materials directly or indirectly related to German history, heritage and tourism (the number of cultural heritage objects preserved to the present day and the number of former German settlements), maps and webobjects.

During the processing of the collected data, as well as to illustrate the results of the study, the following methods were used: historical (to describe the historical preconditions for the formation of the cultural heritage of the German ethnic minority in modern regions of Ukraine); typological (for identifying types of preserved objects); cartographic (to analyze the share of Germans 
within the former provinces and modern regions of Ukraine); analytical and problematic (to identify problems of development of German ethnic tourism in Ukraine), etc. Cluster analysis (Excel software) was also used to group the regions according to the main criteria - the share of preserved objects of German cultural heritage and the share of former German settlements in the context of regions of Ukraine.

\section{Results of the research and their analysis.}

Historical preconditions for the formation and development of the cultural heritage of German ethnic minority on the territory of modern Ukraine

Migration of the ethnic German population to the territory of Ukraine, having passed several stages and directions of settlement, relating to different periods of history and associated with the demographic and sociopolitical situation in both German and Ukrainian lands. The first information about Germans in Ukrainian lands dates back to the princely period of Ukrainian history and dates back to the XIII-XIV centuries. It is known that at that time Germans came from Regeneburg, Mainz, Vienna, Lubeck, where there was an excess of workers in the field of handicrafts, construction, trade, forming small communities in Kyiv, VolodymyrVolynskyi, Lutsk, Lviv. The presence of the German ethnic group of that period immediately affected the architecture of cities and their appearance in general, as the German population predominantly settled compactly in individual neighborhoods, reproducing German residential traditions. Subsequently, this influence became even more significant, as German communities from the XIII century began to grant Magdeburg (German) law, which later extended to all settlements. This meant that the development of such settlements had to take place taking into account certain urban planning standards (the presence of the town hall in the center of the settlement, the central market square, etc.). The first to receive the Magdeburg right were Sianok (1339), Lviv (1356), Kamianets-Podilskyi (1374), Terebovlia (1389), and Sambir (1390). Later, already in the XIV-XVI centuries, during the belonging of Ukrainian lands to the Kingdom of Poland and the Grand Duchy of Lithuania, Magdeburg law spread to other cities of the Right Bank and Left Bank of Ukraine, also contributing to the creation of new urban settlements (Kobyletskyi, 2008). That is, the spread of German legal relations has become an important factor in accelerating the urbanization of Ukraine, linking the development of events in the Ukrainian lands with European processes. At the same time, the granting of the Magdeburg right to the cities became one of the reasons for the growth of foreign ethnic colonization of Ukrainian lands, including German one.

German communities of that time arose not only in cities, but also in rural areas, primarily in the western and eastern parts of Galicia. According to the research of the Austrian historian-ethnographer R.F. Kaindl, which was analyzed by I.S. Monolatii, in this period there were 650 localities, the structure of which was based on German law. In particular, in terms of counties: Old Town (16), Turka (27), Stryi (5), Drohobych (17), Sambir (14), Rudky (9), Mostyska (12), Yavoriv (15), Zhovkva), Gorodok (22), Lviv (38), Bibrka (3), Zhydachiv (4), Dolyna (1), Kalush (2), Stanislaviv (5), Peremyshlyany (4), Sokal (2), Brody (4), Zolochiv (6), Berezhany (4), Pidhaytsi (3), Tovmach (5), Kolomyia (1), Sniatyn (1), Buchach (3), Terebovlia (1), Ternopil (1). The German settlers were mostly peasants, artisans, and merchants from Silesia, the Saar, and the Rhineland (Monolatii, 2002).

In the second half of the XVIII-XIX century a new wave of colonization of the territory of Ukraine by the German people begins, which covered both Ukrainian lands as part of the Russian and Austrian empires. The main centers of German settlement within the Russian Empire were the Lower Dnipro (from the second half of the XVIII century) and Southern Ukraine (from the beginning of the XIX century). The German colonists were mostly peasants from Baden, Württemberg, Hesse and the Palatinate, who settled in southern Bessarabia (Ackerman County), Kherson Province (Odesa, Tiraspol and Kherson Counties), Katerynoslav and Tavriia Provinces. These resettlements were the result of the encouraging policy of the tsarist regime, interested in the rapid socio-economic development of sparsely populated areas, which until recently were the part of the Crimean Khanate. The resettlement of Germans to the territory of Volyn also intensified. According to the 1897 census, 345,000 Germans lived in south of Ukraine, accounting for $4.2 \%$ of the total population of Ukraine, and 171,000 (5.73\%) in Volyn.

After the entry of Bukovyna and Galicia into the Austrian monarchy in the late XVIII century the government of this country also purposefully pursued a policy of resettlement of the German population. These were mostly agricultural workers from Baden, Württemberg, Hesse and the Palatinate and other regions, who settled in Stryi, Dolyna, Drohobych, Kolomyia, Lviv, Stanislav, Rava-Ruska and some other counties (Encyclopedia of Ukrainian Studies, 1996). The process of settlement of Galicia was carried out in two directions: 1) Dobromyl - Stryi - Stanislav (Ivano-Frankivsk); 2) Sambir - Liubachiv - Sokal Radekhiv-Brody-Berezhany. German colonies formed small rural settlements, the number of inhabitants of which ranged from 25 to 100 people. The largest colonies were Josefeberg (573 people) and Brigidau (607 people) in the Sambir district, as well as Landestroy (327 people) and Ugartstal (329 people) in the Stryi district.

A number of German colonies were created even earlier in the Transcarpathian Ukraine, and the total 
German population reached 20 thousand people. Thus, at that time, up to 150 German autonomous settlements emerged on ethnic Ukrainian territory as part of the Austrian Empire. The Austrian government sought to establish new German settlements separately for Protestants and Catholics in order to make it easier and faster to provide religious buildings and educational institutions (Monolatii, 2002).

Although, most German colonies were formed on the plains, German colonization brought some changes to the settlement network of mountainous areas. These were mostly small settlements in the immediate vicinity of Ukrainian villages. While most German colonies in the mountainous Carpathian region of Galicia were mostly agricultural, in Transcarpathia and Bukovyna the establishment of such settlements was due to the needs of forestry and extraction of some mineral resources (Dnistrianskyi, 2019).

Thus, from the end of the XVIII to the beginning of the XIX century the number of the German ethnic minority in the Ukrainian lands increased significantly and according to the censuses of 1897 (in the Russian Empire) and 1900 (in the Austro-Hungarian Empire) totalized 431 thousand people. However, the settlement of ethnic Germans in some regions was significantly differentiated (Fig. 1): its largest concentration (over $10 \%$ ) was in Volyn, Southern Bessarabia and Northern Crimea, the smallest (less than 1\%) - in Podillia and the Left Bank of Ukraine.

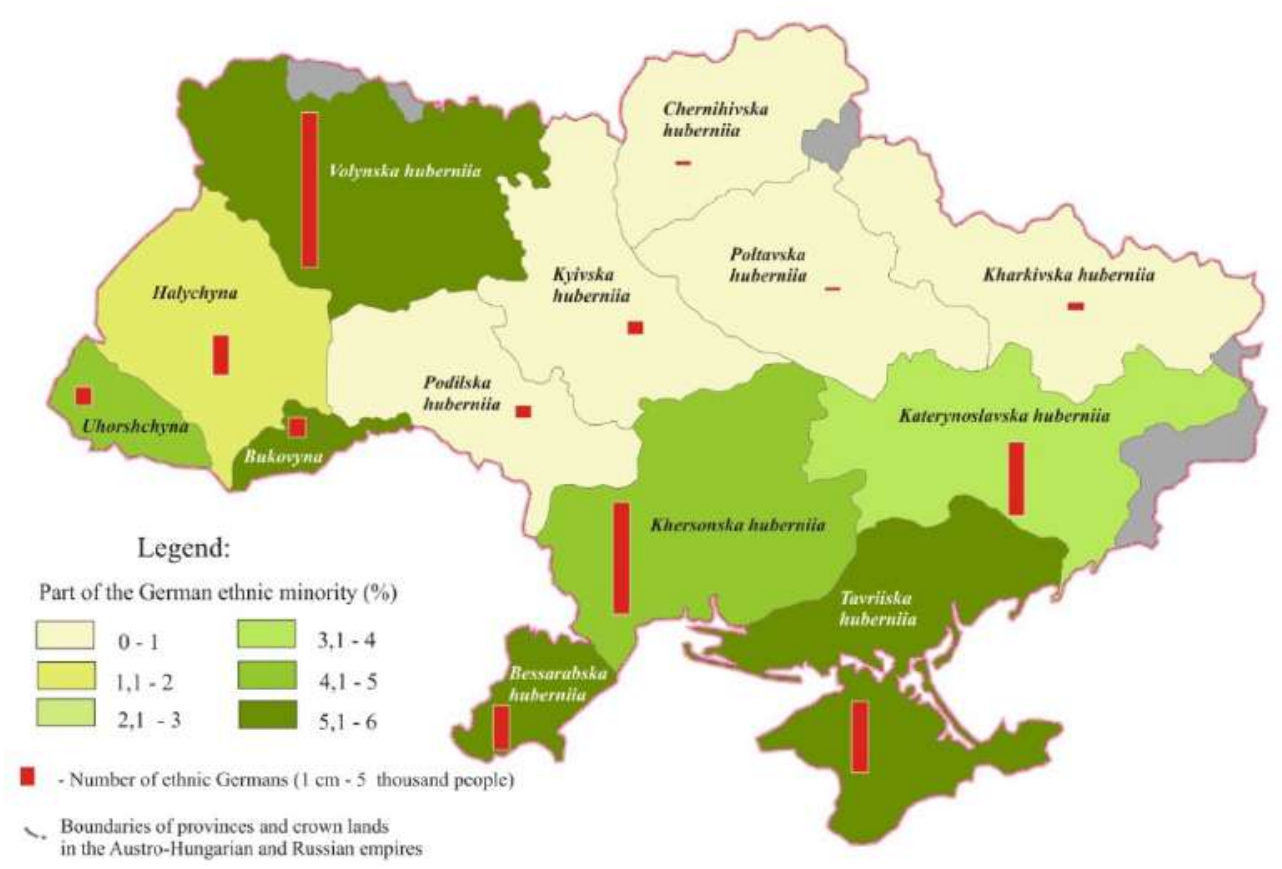

Fig. 1. Geography of the German ethnic minority at the beginning of the XX century within the modern territory of Ukraine (developed by the authors)

In 1939, the German population of Western Ukraine was resettled to Germany in accordance with SovietGerman agreements, and the settlements founded by the Germans were either liquidated or underwent ethnocultural transformation. The fate of the German population was even more tragic, which became the part of the USSR: with the beginning of the GermanSoviet war, in 1941, ethnic Germans were deported to Kazakhstan and Central Asia, suffering huge human losses. Despite the limited number of German settlements, their spread to Ukrainian lands to some extent affected the complexity of construction and planning structure of neighboring Ukrainian villages, some aspects of agricultural production and the formation of cultural landscapes in general.

According to the 2001 census, there were 33.3 thousand Germans in Ukraine: the largest number was in Donetsk (4.6 thousand people), Dnipropetrovsk (3.8 thousand people), Zakarpattia (3.5 thousand people), and Odesa (2.9 thousand people) regions and in the Crimea (2.5 thousand people) (Fig. 2).

Assessment of tourism potential of the regions in the context of the current state of German cultural heritage

We will conduct a cluster analysis based on the grouping of regions of Ukraine according to such indicators as the share of preserved objects of German cultural heritage and the number of settlements founded by ethnic Germans. According to obtained results, we can distinguish three groups of areas. The first group includes areas where the share of preserved objects is less than $2 \%$; to the second - from 2 to $5 \%$; to the third-more than $5 \%$ (table 1 ). 


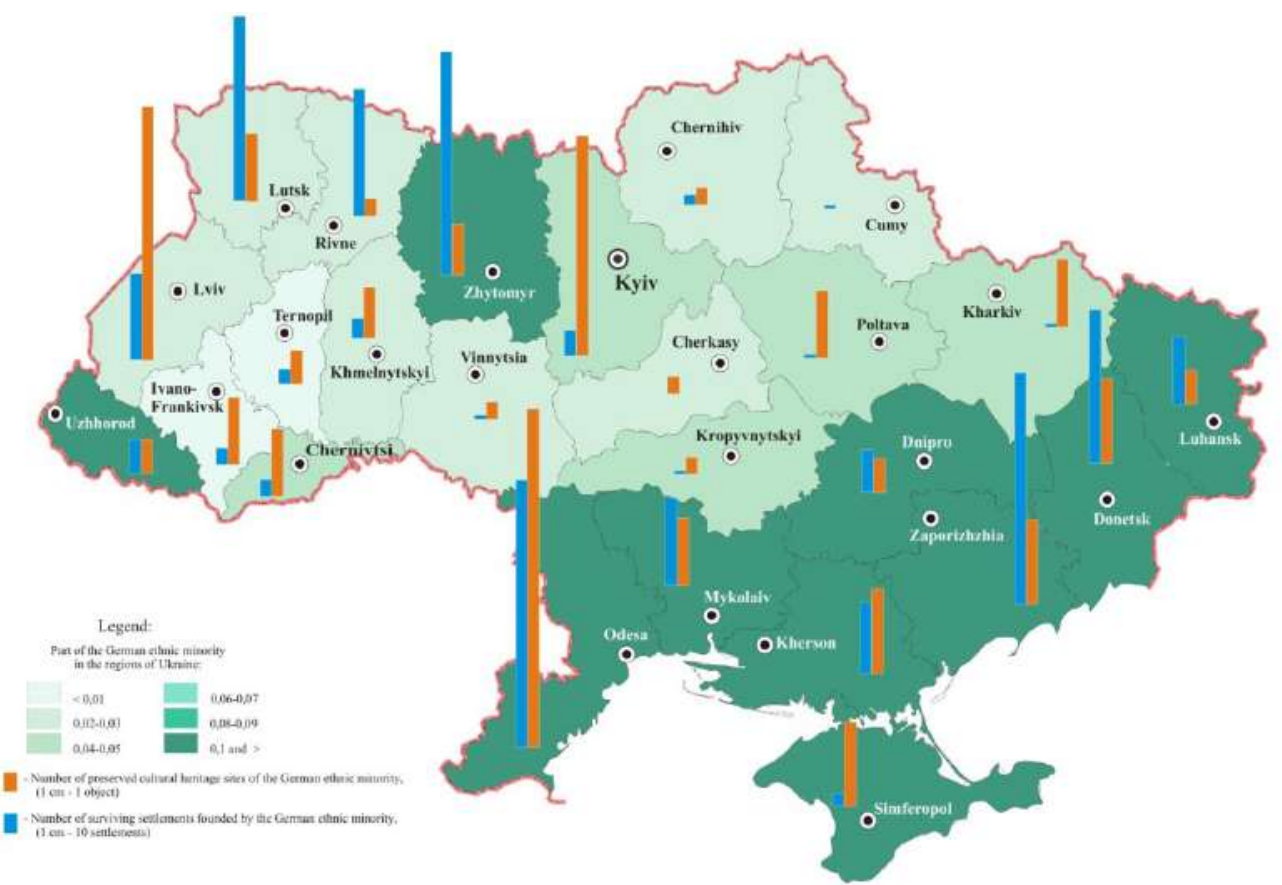

Fig. 2. Geography of ethnic Germans and German cultural heritage in the modern Ukraine (developed by the authors)

Table 1. Cluster analysis of German cultural heritage of the regions of Ukraine (developed by the authors)

\begin{tabular}{|c|c|c|c|}
\hline Group & Region (Oblast) & $\begin{array}{c}\text { Share of preserved } \\
\text { objects, } \%\end{array}$ & $\begin{array}{c}\text { Share of settlements founded by } \\
\text { ethnic Germans, } \%\end{array}$ \\
\hline \multirow{12}{*}{1} & Dnipropetrovska & 1.5 & 2.5 \\
\hline & Rivnenska & 0.7 & 7.4 \\
\hline & Sumska & 0 & 0.2 \\
\hline & Vinnytska & 0.7 & 0.2 \\
\hline & Zakarpatska & 1.5 & 2 \\
\hline & Kirovohradska & 0.7 & 0.2 \\
\hline & Luhanska & 1.5 & 4 \\
\hline & Donetska & 1.5 & 9 \\
\hline & Ternopilska & 1.5 & 0.8 \\
\hline & Kharkivska & 1.5 & 0.2 \\
\hline & Cherkaska & 0.7 & 0 \\
\hline & Chernihivska & 0.7 & 0.6 \\
\hline \multicolumn{2}{|l|}{ Total } & 12.5 & 27.1 \\
\hline \multirow{8}{*}{2} & AR Krym & 3.7 & 0.6 \\
\hline & Volynska & 3.7 & 10.8 \\
\hline & Ivano-Frankivska & 3 & 1 \\
\hline & Mykolaivska & 3 & 5.1 \\
\hline & Poltavska & 3 & 0.2 \\
\hline & Khersonska & 3.7 & 4.2 \\
\hline & Khmelnytska & 2.2 & 1.2 \\
\hline & Chernivetska & 3 & 1 \\
\hline \multicolumn{2}{|l|}{ Total } & 25.3 & 24.1 \\
\hline \multirow{5}{*}{3} & Kyivska & 9.7 & 1.5 \\
\hline & Lvivska & 15 & 5 \\
\hline & Zaporizka & 10.4 & 13.6 \\
\hline & Zhytomyrska & 6 & 13.1 \\
\hline & Odeska & 21.1 & 15.6 \\
\hline \multicolumn{2}{|l|}{ Total } & 62.2 & 48.8 \\
\hline
\end{tabular}

developed by the authors 
According to the results of cluster analysis, the leaders among the regions of Ukraine by the number of objects of German cultural heritage are Odesa, Lviv, Zaporizhzhia, Kyiv and Zhytomyr regions. They are characterized by a high number of preserved objects $(62.2 \%)$ and a significant number of settlements $(48.8 \%$ of the total number in Ukraine). These areas have the greatest potential for the development of German ethnic tourism. The second group of regions is characterized by the medium number of preserved objects $(25.3 \%)$ and the number of settlements $(24.1 \%$ of the total number in Ukraine). They also have sufficient potential for the development of ethnic tourism. The first group of region has the lowest share of preserved objects $(12.5 \%)$, although it has a slightly higher share of settlements than in the regions of the second group (27.1\%).
Among the regions of Ukraine, the largest number of German settlements was in Odesa (158 units or $15.6 \%$ of the total number in Ukraine), Zaporizhzhia (137 units or $13.6 \%$ ), Zhytomyr (132 units or $13.1 \%$ ) and Volyn regions (109 units or $10.8 \%$ ). The smallest number of German colonies was in Cherkasy, Poltava, Kirovohrad, Vinnytsia, Kharkiv and Sumy regions. Few objects of German cultural heritage have been preserved in these areas. There are areas where the number of former German settlements is high, but few objects of German cultural heritage have been preserved, in particular, Rivne, Donetsk and Volyn regions.

Based on this analysis, seven main types of preserved objects of German cultural heritage in Ukraine were identified (Fig. 3). Sacred objects, in particular Lutheran churches, and public buildings and structures, in particular, schools and gymnasiums, are best represented in Ukraine.

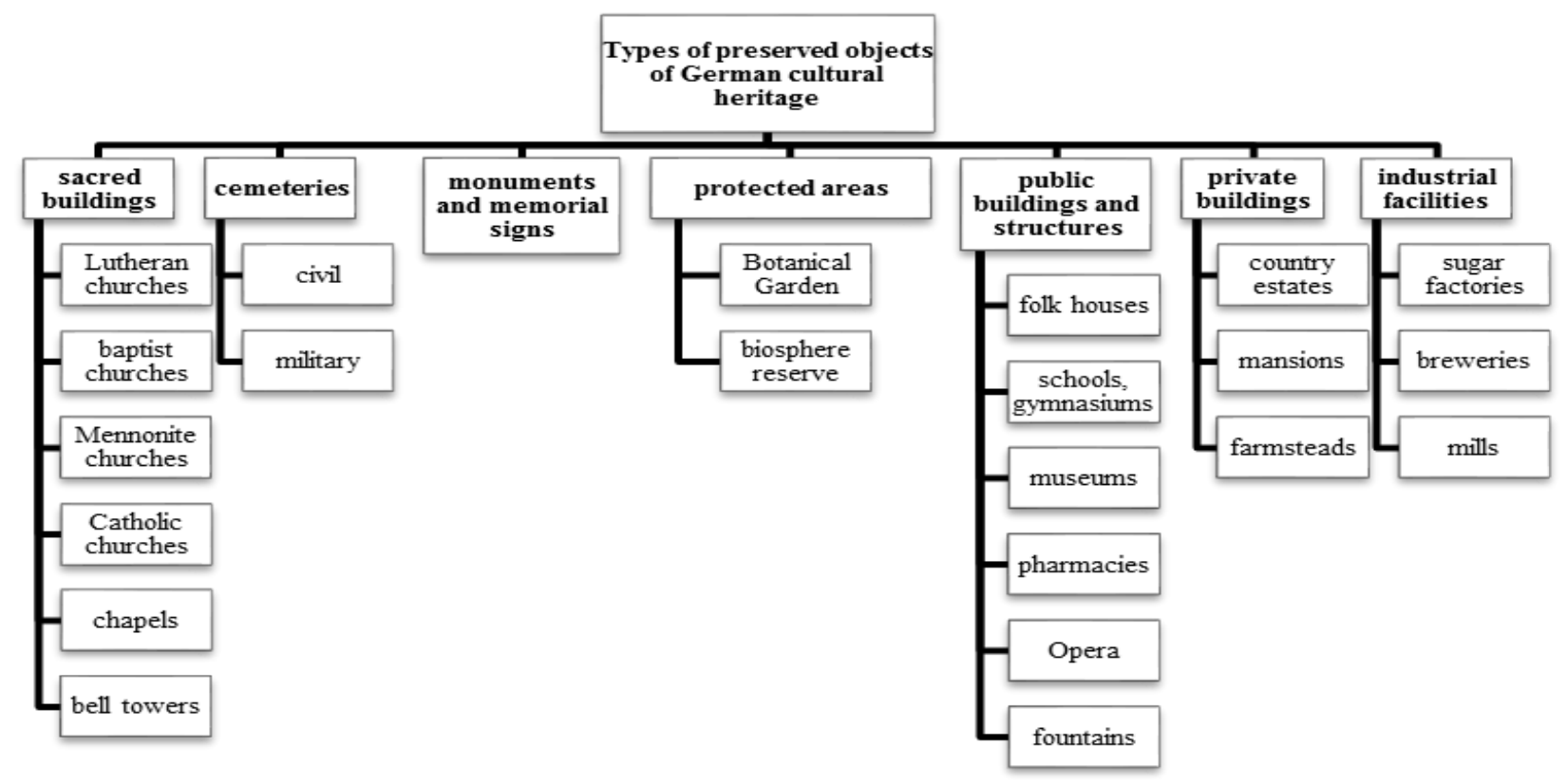

Fig. 3. Types of preserved objects of German cultural heritage in Ukraine (developed by the authors)

To assess the tourism potential of the cultural heritage objects of the German ethnic minority, the geography of their distribution is important. Thus, Odesa region has a strong potential for the development of ethnic tourism due to the largest number of preserved objects of cultural heritage of ethnic Germans in Ukraine, in particular, churches, cemeteries, monuments, farmsteads, museums. The contribution of German colonists to the development of villages and towns in the region is especially significant and is evident even now. For example, a unique water supply system built by the Germans is still used in the village Tarutyne. Some temples impress with their style and decoration. Once the largest Catholic cathedral in southern Ukraine the Cathedral of the Assumption of the Blessed Virgin Mary - was built by the Germans in the village
Lymanske (former German settlement of Zelts) on the model of the cathedral in Zaltsburz (Austria). Now the monument needs to be restored. The town also has a museum of German colonists.

A large number of interesting objects of German cultural heritage are located in the Lviv region, in particular: the Church of the Nativity of St. Ivana Khrestytelia, the former Lutheran church and the German cemetery in Vynnyky; Church of St. Ursula and the Greek Catholic Church of St. Clement the Pope in Lviv, which was designed in the late nineteenth century by german architect Frans Shtats; Evangelical Church in Pidhaichyky, built in 1910.

The largest military memorial complex of German burials in the Lviv region and a church in the village Potelychi deserve the attention of tourists (Dorosh, Y., 
2020); a German chapel, a former German school and a German cemetery in village Piatnychany; churches in the villages of Yosypivka, Ushkovychi, Sapizhanka; ethnographic museum of Galician Germans in the village of Nyzhni Gaii. In the former German colony of Dornfeld (now the village of Ternopillia) a church, a former German people's house, a school, a mill and a parish have been preserved.

Among the eastern regions of Ukraine, Zaporizhia region has the largest number of German cultural heritage objects. In particular, it is the church of Christ the Savior in Berdiansk, as well as churches in the villages of Kutuzivka and Tersyanka. A house-museum of German colonists in the village of Ruchaivka has been preserved, the founder of which is considered to be Victor Dick. Many objects have been preserved in the former German colony of Verkhnia Khortytsia (Zaporizhzhya): mennonite church (now the House of culture), school for girls, hospital complex, Valman Castle. The oldest preserved cemetery in Zaporozhzhia with German burials is located on the island of Khortytsia. There are a large number of historical heritage objects in the former colony of Halbshtadt (now city Molochansk), including the Wilms House, a school for girls, a Mennonite school for boys, the Wilms Mill, and the Shreder House. In the village Mirske (former colony of Mirau) there is a church built in the second half of the XIX century, which is located on the outskirts of the settlement and is half-destroyed. The ruins of the Catholic church in the village Sviatotroitsk have been preserved (former colony of Eikhvald), built in 1871.

There are a number of interesting objects of German cultural heritage in the Kyiv region. In particular, the oldest botanical garden in Kyiv (named after Academician O. V. Fomin), which was founded by the German botanist Ernst Rudolf von Trautfetter in 1839. The first German private museum-pharmacy has also been preserved in Kyiv. There are a number of notable buildings and structures built by German architects, including Baron Steingel's house, the Southwestern Railway Administration building, the Weeping Widow's House, the Kyiv Opera House, the bell towers of the Kyiv-Pechersk Lavra and St. Sophia Cathedral (Sait Goethe-Institut v Ukraini).in Ukraine). The German mountain, which is also called the Lutheran mountain is an attractive tourist destination. This is the historical name of a small district of Kyiv, where the Church of St. Catherine has been preserved, in front of which a memorial "Sorrowful Angel" was built in memory of the deportation of Germans from Ukraine during the Second World War.

The following sacred objects of German origin have been preserved in Zhytomyr region: the Lutheran Church in Zhytomyr, the churches in the villages of Zazdrivka and Viazovets. Noteworthy is Himmler's headquarters called "Hegewald", built in 1941-1942 in the forest (Sulimenko, 2009).

The group of regions with a medium level of potential of German ethnic tourism includes: Crimea, Volyn region, Kherson region, Ivano-Frankivsk region, Mykolaiiv region, Poltava region, Chernivtsi region and Khmelnytskyi region.

The potential of the Crimean peninsula in the context of the development of ethnic tourism, unfortunately, is limited due to the Russian occupation and the uncertain state of the cultural heritage objects themselves, including the German one. Among the preserved objects are: Kessler-Fersman Castle in Lozove, Milhausen estate and the current church in Simferopol, the current church of St. Mary in Yalta and the former Lutheran church in Sudak.

In the Volyn region there are three well-preserved churches - Lutheran churches in Lutsk, in the village Oleshkovychi and in the city of Volodymyr-Volynskyi. Another church in the town of Rozhysche is in ruined state (Shovchko; Nadolska, 2004).

Kherson region has a relatively small number of preserved objects. The Askania-Nova Nature Reserve, founded in 1898 by the German naturalist Friedrich Falz-Fein, is unique. The festival of German culture "Kronau Fest" in the village Vysokopillya (former German colony of Kronau) is famous in the region, where the old German gymnasium, the building of the former church and the German cemetery have also been preserved.

Regarding Ivano-Frankivsk region, it is also referred to the group of regions with a medium level of ethnic tourism potential. Important objects of German cultural heritage are: the buildings of the former German gymnasium in Ivano-Frankivsk, the orphanage "Bethlehem", the German school, the former German People's House. The Lutheran Church in Kolomyia is also known in the region, which was built in 1873-1875; now it is the Church of St. Nicholas of the Ukrainian Greek Catholic Church.

Among the cultural heritage objects of the German ethnic minority in the Mykolaiiv region are the ruins of former churches, in particular, the Church of St. George in the village of Krasnopillya and the Church of St. Antoine of Padua in the village of Novoselivka. However, in Mykolaiiv there is a functioning Lutheran church of Christ the Savior.

Preserved German cultural objects located in the Chernivtsi region are Lutheran churches in the village Hlyboka and Chernivtsi. The German People's House in Chernivtsi, built in the early XX century, which was the center of German cultural and social life in Chernivtsi and Bukovyna.

As for the Poltava region, it should be noted that the houses of ancient architecture, built by German 
colonists are preserved to this day in Poltava, on the streets of Skovoroda, Balakin and Morgun.

In the Khmelnytskyi region, German cultural heritage is represented by the Lutheran Church in Dunaiivtsi and the Lutheran Church in Kamianets-Podilskyi, which is now replaced by a children's and youth sports school (Hradun, E. Iu., \& Tomilevych L.V., 2016). There are industrial facilities built by the Germans in the region: one of the oldest sugar factories in Ukraine in Gorodok, Khmelnytskyi region, as well as a brewery in Proskuriv (today the company is called "Khmelpivo").

Let us consider the regions that according to the cluster analysis are classified as regions with a low number of preserved objects and settlements.

In the Ternopil region, objects of German cultural heritage are represented by a church in the village of Novosilky, but now the building is in a ruined state and needs reconstruction. In 1821, Jan von Konopka opened a boarding house near Mykulyntsi on the basis of hydrogen sulfide mineral springs. Now it is a sanatorium "Medobory" in the village Konopkivka near the town of Mykulyntsi (Volovyk, Yatsiuk, 2017).

In the Cherkasy region, the only object that remains to this day is the former Lutheran church in Uman, which is owned by the community of the Evangelical Baptist Church.

In the Vinnytsia region, one of the centers of German settlements was the town of Nemyriv, which had a functioning Lutheran church, which was converted into a fire station during the Soviet era. The German cemetery has also survived to this day.

It is worth paying attention to Zakarpattia region. The most attractive preserved object in the region is the former residence and hunting lodge of the Counts of Schönborn in the village of Chynadiievo. Schönborn Castle is now a sanatorium "Carpathians", an architectural monument of national importance. There is also a German house in the village that unites ethnic Germans. Worth noting is the village of Nimetska Mokra, which was founded by colonists from Upper Austria in 1775. The church of St. John of Nepomuk, built in 1780, is still preserved in this village. It is the only preserved wooden church of the Germans of Zakarpattia.

An interesting object is the Evangelical Lutheran Church of St. Catherine in Dnipro. A mural was created in Kharkiv for part of the $25^{\text {th }}$ anniversary of UkrainianGerman diplomatic relations. The German military cemetery is also preserved here.

Problems and prospects of development of German ethnic tourism in Ukraine

Analyzing the existing objects of German cultural heritage in Ukraine, we can note that many of them are destroyed or half-destroyed, so it is necessary to restore and promote them. A partial solution to the problem of lack of public funding may be the transfer of facilities in need of restoration to the ownership of private investors. They will invest in historic objects rather than ordinary ones. The uniqueness and value of historic real estate will help fill local budgets. Historic public spaces (squares, streets) can become a venue for fairs, festivals and more. Some churches can be transferred to other denominations, thanks to which they would be restored (this is how a wooden church in the village of Nova Lypivka in Ivano-Frankivsk region was restored).

In the European countries, particularly, in Germany, owners who restore cultural objects, tax rebates, soft loans, etc. are encouraged. It is expedient to introduce such a practice in Ukraine as well. In recent years, grant programs, most often funded by European organizations, have become popular. In view of this, it is advisable to attract grant funds for the restoration of German cultural heritage.

Legislation needs to be improved to ensure the protection and preservation of historical and cultural heritage by state and local authorities, as well as to oblige owners to keep their facilities in good condition. To date, Ukraine has not developed a sustainable model for the preservation of historical and architectural heritage. Budget expenditures for cultural heritage activities are constantly declining. The state policy of cultural heritage protection is based on the Law "On Protection and Preservation of Immovable Cultural Heritage of Ukraine", but the current system of state control over cultural heritage preservation is not effective, a significant amount of functions is transferred to places, but they are unable to perform financial ones. Ukraine lacks the successful experience of private initiative or public-private partnership to preserve historical and cultural heritage.

Another important task is to involve the public in the preservation of cultural heritage. Public involvement and participation will contribute to the sustainable development and preservation of cultural and historical heritage. The public-private partnership will focus public and private initiatives on the development and maintenance of historic objects for the benefit of communities, including employment, education, tourism and general awareness of cultural value. The descendants of German colonists who went abroad are most interested in the German historical and cultural heritage. They often come to their native lands and finance various projects. That is why it is important to promote German cultural heritage objects. One of the popularization ways can be the organization of a virtual museum or virtual exhibitions, as well as certification and inclusion in the national electronic information resource of cultural heritage, conferences, round tables and more. 


\section{Conclusions.}

Ukraine has a rich cultural heritage, including German. As the state seeks to integrate into the world cultural space, the study of cultural heritage, its preservation is an important task of national importance. Historic objects are the key to sustainable development of the country. The protection of cultural heritage is an international legal obligation of our state to the world community. This encourages the analysis of the state of historical objects, the directions of activation of all components of their potential. Their recovery will contribute to the development of the country's economy, tourism and improve living standards. The main centers of development of German ethnic tourism can be Odesa, Lviv, Zaporizhzhia, Kyiv and Zhytomyr regions. In addition, a number of regions oblsthave a slightly lower but sufficient tourism potential that needs to be developed (Crimea, Volyn, Kherson, Ivano-Frankivsk, Mykolaiiv, Poltava, Chernivtsi and Khmelnytskyi regions). Many German cultural heritage objects in Ukraine are abandoned and in need of restoration, so a serious problem is the insufficient state funding for appropriate measures for their preservation and restoration. To develop German ethnic tourism and improve the state of German cultural heritage in Ukraine, it is advisable to promote, study and implement foreign experience, in particular, in financing, management, legislative regulation of heritage, develop tourist routes with different types of objects, attract sponsors (in particular, among German descendants), participate in grant programs, etc. An important role here is given not only to the state, but also to the local governments and the public.

\section{References}

Baitsar, A., 2013. Heohrafiia nimetskykh poselen $u$ Vynnykakh (v konteksti rozvytku etnokulturnoho turyzmu) [Geography of German settlements in Vynnyky (in the context of ethnocultural tourism development)]. Visnyk Lvivskoho universytetu. Seriia heohrafichna.Visnyk of the Lviv University. Series of geography, 43, 11-16 Retrieved form: http://old.geography.Inu.edu.ua/ Publik/Period/visn/43(1)/index43(1).html (In Ukrainian).

Bidenko, N., 2012. Staryu dancing - pershe nimecke poselennia na terytorii Kirovogradskoi oblasti [Old Danzig is the first German settlement in the Kirovohrad region]. Naykovi zapysy Kirovogradskoho derzavnoho pedahohichnoho universytetu V. Vynnychenka, 16, 63-69. Retrieved from: http://nbuv.gov.ua/UJRN/ $\mathrm{Nz}$ i_2012_16_11 (In Ukrainian).

Dnistrianskyi, M. S., 2019. Rol riznospriamovanykh kolonizatsiinykh rukhiv u zaselenni Ukrainskykh Karpat uprodovzh XIII - pershoi polovyny XIX st [The role of multidirectional colonization movements in the settlement of the Ukrainian Carpathians during the XIII - first half of the XIX century]. Lviv: LNU imeni Ivana Franka. Retrieved from: https://geography.lnu. edu.ua/wp-content/uploads/2020/02/Maket-Dnistrianskyy-1-116.pdf (In Ukrainan).

Dorosh, Y., 2020. Nimetska istoryko-kulturna spadshchyna yak resurs dlia rozvytku nostalhiinoho turyzmu u Lvivskii oblasti [German historical and cultural heritage as a resource for the development of nostalgic tourism in the Lviv region]. Visnyk Kyivskoho natsionalnoho universytetu kultury i mystetstv. Seriia: Turyzm. Bulletin of Kyiv National University of Culture and Arts. Series in Tourism, 1, 115-127 Retrieved from: https://doi.org/10.31866/2616-7603.3.1.2020.207515 (In Ukrainian).

Graham Brooks, 2011. Heritage as a driver for development Its contribution to sustainable tourism in contemporary society, 497-505. Retrieved from: https://openarchive. icomos.org/id/eprint/1207/1/III-1-Article1_Brooks.pdf.

Hnes, L.B., 2004. Nimetski kolonii Halychyny v riznykh sotsialno-ekonomichnykh formatsiiakh [German colonies of Galicia in various socio-economic formations]. Visnyk Natsionalnoho universytetu "Lvivska politekhnika"Bulletin of the National University "Lviv Polytechnic", 505, 174-178. Retrieved from: http://ena.lp.edu.ua:8080/ bitstream/ntb/9609/1/23.pdf (In Ukrainan).

Hradun, E. Iu., \& Tomilevych L. V., 2016. Problemy ta perspektyvy doslidzhennia kulturnoi spadshchyny m. Dunaivtsi Khmelnytskoi oblasti [Problems and prospects of research of cultural heritage of Dunaivtsi, Khmelnytsky region]. Sivershchyna v istorii Ukrainy: Zb. nauk. pr.-Severshchyna in the history of Ukraine: Coll. Science. ave., 9, 33-39. Retrieved from: http://nz-hlukhiv.com.ua/wp-ontent/uploads/sivershuna/ sivershuna_2016.pdf(In Ukrainian).

Kobyletskyi, M.M., 2008. Mahdeburzke pravo v Ukraini: XIV - poch. XIX st. Istoryko-pravove doslidzhennia [Magdeburg law in Ukraine: XIV - beg. XIX century Historical and legal research]. Lviv: PAIS (In Ukrainan).

Monolatii, I., 2000. Nimetski kolonii Halychyny v tablytsiakh. Dovidnyk [German colonies of Galicia in the tables. directory]. Kolomyia. Retrieved from: https://kalusz.io.ua/s120978/nimecki_kolonie_galichini (In Ukrainan).

Monolatii, I.S. 2002. Vid kontaktiv do spivpratsi: sotsialnoekonomichne stanovlennia ta kulturnyi rozvytok nimtsiv u Halychyni [From contacts to cooperation: socio-economic formation and cultural development of Germans in Galicia]. Kolomyia: Vydavnytstvapolihrafichne tovarystvo "Vik" (In Ukrainan).

Nadolska, V., 2004. Nimtsi na Volyni: etapy rozvytku diaspory i suchasne natsionalno-kulturne vidrodzhennia [Germans in Volhynia: stages of diaspora development and modern national and cultural revival]. Etnichna istoriia narodiv Yevropy - Ethnic history of the peoples of Europe, 16, 114-119. Retrieved from: https://evnuir. 
vnu.edu.ua/bitstream/123456789/935/3/16 19.pdf (In Ukrainan).

Nimci u Xersonskiy oblasti [Germans in the Kherson region]. Retrieved from: https://lib.kherson.ua/n-i-n_nimtsi.htm (In Ukrainian)

Nimetski slidy v Ukraini [German traces in Ukraine]. Sait Goethe-Institut v Ukraini - Goethe-Institut website in Ukraine. Retrieved from: https://www.goethe.de/ins/ $\mathrm{ua} / \mathrm{uk} / \mathrm{kul} / \mathrm{sup} / \mathrm{dsu} / \mathrm{art} . \mathrm{html}$ (In Ukrainan).

Nimtsi na Ukraini. Entsyklopediia Ukrainoznavstva [Germans in Ukraine. Encyclopedia of Ukrainian Studies]. 1996, Lviv, Vol.5, 1768-1774. Retrieved from: http://izbornyk. org.ua/encycl/euii133.htm (In Ukrainan).

Polyvach, K.A., 2012. Kulturna spadshchyna ta yii vplyv na rozvytok rehioniv Ukrainy [Cultural heritage and its impact on the development of the regions of Ukraine]. Kyiv: Instytut heohrafii NAN Ukrainy. Retrieved from: https://igu.org.ua/objects/default/files/pdf-text/ PolyvachK Heritage.pdf (In Ukrainian).

Shovchko, V. Liuteranska kirkha Volodymyr-Volynskoho [Lutheran Church of Volodymyr-Volynsky] Retrieved from: https://zabytki.in.ua/uk/2236/lyuteranska-kirkhavolodimir-volinskogo (In Ukrainan).

Silberberg, T., 1995. Cultural tourism and business opportunities for museums and heritage places. Tourism Management, 16(5), 361-365.

State Statistics Committee of Ukraine: All-Ukrainian Census 2001. Retrieved from: http://2001.ukrcensus.gov.ua/

Stern, B.,1992. Historical and personal nostalgia in advertising text: The fin de sie'cle effect. Journal of Advertising, 21(4), 11-22.
Sulimenko, O., 2009. Nimetska kolonizatsiia volynskoi hubernii v kintsi XVIII - 70-Kh rr. XIX st [German colonization of the Volyn province in the late XVIII 70's of the XIX century]. Retrieved from: http://eprints. zu.edu.ua/4862/1/Sulimenko_2.pdf (In Ukrainan).

Terebukh, A.A., Moroz, O.I., 2016. Otsiniuvannia turystychnoho potentsialu destynatsii [Estimation of tourism potential of destinations]. Aktualni problemy ekonomiky - Current problems of the economy, 7(181), 335-343 (In Ukrainian).

Timothy, D.F., 2011. Cultural Heritage and Tourism: An Introduction; Chanel View Publications: Bristol, UK.

UNESCO. Mexico City Declaration on Cultural Policies World Conference on Cultural Policies Mexico City, 26 July-6 August 1982. Retrieved from: https://culturalrights.net/descargas/drets_culturals401. pdf.

Volovyk, V. \& Yatsiuk, V., 2017. Nimetski silski etnokulturni landshafty Podillia XIX - pochatku XX storichchia [German rural ethnocultural landscapes of the 19th early 20th centuries]. Visnyk Kyivskoho natsionalnoho universytetu imeni Tarasa Shevchenka-Bulletin of Taras Shevchenko National University of Kyiv, 3-4 (68-69), 103-107 (In Ukrainan).

Volovyk, V. \& Yatsiuk, V., 2017. Nimetski silski etnokulturni landshafty Podillia XIX - pochatku XX storichchia [German rural ethnocultural landscapes of the 19th early 20th centuries]. Visnyk Kyivskoho natsionalnoho universytetu imeni Tarasa Shevchenka, Geografiya Bulletin of Taras Shevchenko National University of Kyiv, Geography, 3-4 (68-69), 103-107. Retrieved from: http://doi.org/10.17721/1728-2721.2017.68.19 (In Ukrainian). 